\title{
Judicial Enforcement and Implementation of EAC Law
}

\author{
James Otieno-Odek
}

\subsection{Introduction}

The East African Community law is found in the Treaty for the Establishment of the East African Community (the EAC Treaty), its Protocols, Directives of the Council of Ministers and Acts of the East African Legislative Assembly (the Assembly) and decisions of the East African Court of Justice (EACJ). The Protocol on the Establishment of the East African Customs Union sets out the customs law of the Community to include the relevant provisions of the Treaty; the Customs Union Protocol; regulations and directives made by the Council; applicable decisions of the EACJ; Acts of the Community enacted by the Assembly and relevant principles of international law. ${ }^{1}$ On matters pertaining to implementation of the Treaty, Community organs, institutions and laws take precedence over similar national ones. ${ }^{2}$

The EAC Treaty establishes the EACJ as the judicial organ of the Community. ${ }^{3}$ The Court is made up of two divisions: First Instance Division and the Appellate Division. Cases are lodged before the First Instance Division and an aggrieved party may institute appeal before the Appellate Division. The First Instance Division is at any given time composed of not more than ten Judges whereas the Appellate Division is comprised of five Judges. ${ }^{4}$ The EAC Treaty allows national courts of the Partner States to adjudicate on issues involving the Community. However, decisions of the EACJ on the interpretation and application of the Treaty take precedence over decisions of national courts on similar matters. ${ }^{5}$

\footnotetext{
1 Article 39 of the Customs Union Protocol.

2 Article 8 (4) of the EAC Treaty.

3 Article 23 of the EAC Treaty stipulates that the Court shall be a judicial body which shall ensure the adherence to law in the interpretation and application of and compliance with the Treaty.

4 Article 24 (2) of the EAC Treaty.

5 Article $33(2)$ of the EAC Treaty.
}

(C) JAMES OTIENO-ODEK, 2017 | DOI 10.1163/9789004322073_030

This is an open access chapter distributed under the terms of the CC-BY-NC License.es otieno-0dek - 9789004322073 
Primarily, the EACJ has jurisdiction over interpretation and application of the EAC Treaty. ${ }^{6}$ The Court's jurisdiction includes advisory and arbitral jurisdiction and any such jurisdiction that may be conferred upon it any time by the Council of Ministers. The jurisdiction of the Court has since been extended to cover trade and investment disputes. ${ }^{7}$

The execution of a judgment of the EACJ which imposes pecuniary obligation on a person is governed by the rules of civil procedure in force in the Partner State in which execution is to take place. ${ }^{8}$ Judgments of the Court are enforced and executed at national level by the Partner States.

This Chapter is a snapshot of the emerging jurisprudence from the EACJ and a preview of how EAC Partner States are enforcing and implementing the Community law in their national jurisdictions. In appraising how the Partner States are enforcing and implementing the community law, it is vital to note that in the case of Timothy Alvin Kahoho-v-The Secretary General of the EAC, ${ }^{9}$ the EACJ observed that the Summit ${ }^{10}$ is the driver of of East African integration and political federation. In Peter Anyang Nyongo- $-v$ - The Attorney General of the Republic of Kenya, ${ }^{11}$ the EACJ held that a Partner State may not invoke the provisions of its internal law as a justification for its failure to perform obligations under the EAC Treaty. The Court expressed that it cannot be lawful for a State which has voluntarily entered into a Treaty with other States by which rights and obligations are vested not only on the State parties but also on their people, to plead that it is unable to perform its obligations because its laws do not permit it to do so. In Henry Kyarimpa-v-Attorney General of Uganda, ${ }^{12}$ the Appellate Division of the EACJ expressed that in adjudging an impugned State action as being internationally wrongful, the Court asks itself the question not whether such action is in conformity with internal law, but rather whether it is in conformity with the EAC Treaty. The Court found that where the complaint

6 Article 21 (1) of the EAC Treaty.

7 On 3 oth November, 2013, the Summit of the EAC Head of States approved the Council of Ministers' decision to extend the Courts jurisdiction to include matters of trade, investment and EAC Monetary Union. To this end, the Partner States of the Community will need to agree a Protocol tooperationalize the extended jurisdiction as per Article 27(2). Article 44 of the EAC Treaty.

9 Appeal No. 2 of 2013.

10 Article 9 (1) (a) of the EAC Treaty establishes the Summit as an organ of the Community. In Article 10 (1), the Summit consists of the Heads of State or Government of the Partner States. In Article 11 (1), the Summit gives the general directions and impetus as to the development and achievement of the objectives of the Community.

12 EACJ Appeal No. 6 of 2014. 
is that the action was inconsistent with internal law and, on that basis, a breach of a Partner State's obligation under the EAC Treaty to observe the principle of the rule of law, it is the Court's inescapable duty to consider the internal law of such Partner State in determining whether the conduct complained of amounts to a violation or contravention of the Treaty. ${ }^{13}$

\subsection{Emerging Jurisprudence from the EACJ on Interpretation of the Treaty}

The EACJ is very active in the interpretation of the EAC Treaty. The Court has expressed that the Community is a people centered and market-driven cooperation, ${ }^{14}$ and in this regard, consultation and participation of the people outside the Summit and other organs of the Community is imperative. In the case of East Africa Law Society and 4 others v. Attorney General of Kenya and 3 others, ${ }^{15}$ the Court expressed:

It is common knowledge that the private sector and civil society participated in the negotiations that led to the conclusion of the Treaty among the Partner States and, as we have just observed, that they continue to participate in the making of Protocols thereto. Furthermore, as we noted earlier in this judgment, Article 30 entrenches the people's right to participate in protecting the integrity of the Treaty. We think that construing the Treaty as if it permits sporadic amendments at the whims of officials without any form of consultation with stakeholders would be a recipe for regression to the situation lamented in the preamble of "lack of strong participation of the private sector and civil society" that led to the collapse of the previous Community....Failure to carry out consultation outside the Summit, Council and the Secretariat was inconsistent with a principle of the Treaty and therefore constituted an infringement of the Treaty $(\ldots)$

13 The Court took a similar view in the case of Plaxeda Lugumba v. The Secretary General of the East African Community, Reference No. 8 of 2010 (First Instance Division); and The Attorney General of Rwanda v. Plaxeda Lugumba, Appeal No. 1 of 2012 (Appellate Division).

14 Article 7 (1) of the EAC Treaty.

15 EACJ Reference No. 3 of 2007. 
Another notable statement from the EACJ relates to the interpretation of the principle of variable geometry. Article $7(1)$ of the EAC Treaty identifies the principle of variable geometry as one of the operational principles in the integration of the Community. Variable geometry is defined in Article 1 of the EAC Treaty to mean the principle of flexibility which allows for progression in co-operation among a sub-group of members in a larger integration scheme in a variety of areas and at different speeds. Article 7(1) (e) of the EAC Treaty describes the principle of variable geometry as one which allows for progression in co-operation among groups within the Community for wider integration schemes in various fields and at different speeds.

In the Advisory Opinion in Reference by Council of Minister, ${ }^{16}$ the Court opined that variable geometry is intended to allow those Partner States who cannot implement a particular decision simultaneously or immediately to implement it at a suitable certain future time or simply at a different speed while at the same time allowing those who are able to implement immediately to do so. The Court held that the principle of variable geometry is a strategy of implementation of Community decisions and a guide to the integration process.

On locus standi of individuals to bring action alleging violation of the EAC Treaty, the Court in Peter Anyang Nyongo - v- The Attorney General of the Republic of Kenya ${ }^{17}$ expressed that under Article 30 (1) of the EAC Treaty, a claimant is not required to show a right or interest that was infringed or damage that was suffered as a consequence of the matter complained about but that it is enough if it is alleged that the matter complained of infringes a provision of the Treaty in a relevant manner. This principle was equally applied in Samuel Mukira Muhochi-v-Attorney General of the Ugand ${ }^{18}$ where the Court held that once there is an allegation of infringement of the provision of the EAC Treaty, the Court has jurisdiction to interpret and apply the provisions alleged to be infringed under the powers conferred on it by Articles 23 (1) and 27 (1) of the EAC Treaty. It must be noted that in Peter Anyang' Nyong'o- $v$-The Attorney General of the Republic of Kenya ${ }^{19}$ the EACJ held that exhaustion of local remedies is not a pre-condition for accessing the Court.

In relation to Bills presented before the Assembly, the EACJ in the case of Callist Andrew Mwatella \& 2 others vs. East African Community, ${ }^{20}$ held that all

\footnotetext{
16 EACJ Application No. 1 of 2008.

17 EACJ Reference No. 1 of 2006.

18 EACJ Reference No. 5 of 2011.

19 EACJ Reference No. 1 of 2006.

$20 \quad$ EACJ Reference No. 1 of 2005.
} 
Bills introduced into the Assembly belong to the Assembly, whether tabled initially by way of Private Members' Bills, Community Bills or by the Council of Ministers. As such, permission of the Assembly is required to withdraw any Bill from the House.

\subsection{Emerging EACJ Jurisprudence on the Rule of Law and Human Rights}

The rule of law is the sine qua non of any democratic society. In Baranzira Raphael \& another-v-Attorney General of the Republic of Burundi, ${ }^{21}$ the First Instance Division of the Court examined the concept of rule of law. Quoting from a UN Report, the court stated:

The concept of the rule of law refers to the principle of governance to which all persons, institutions and entities, public or private, including the State itself, are accountable to laws that are publicly promulgated, equally enforced and independently adjudicated and which are consistent with international human rights norms and standards. It requires, as well, measures to ensure adherence to the principle of supremacy of the law, equality before the law, accountability to the law, fairness in the application of the law, separation of power, participation in decision making, legal certainty, avoidance of arbitrariness and procedural and legal transparency. (See Report of the (UN) Secretary General on the Rule of Law and Transitional Justice in Conflict and Post-Conflict Societies, UN Doc.5/2004/616 (2004) para.6)

The Appellate Division of the EACJ has had occasion to pronounce itself on the need for an applicant to prove the allegations made in a complaint or reference. In Union Trade Centre Limited - $v$ - The Attorney General of Uganda, ${ }^{22}$ the Appellate Division observed that in law, pleadings in court (whether in the form of Reference, Response to Reference, Notice of Motion, Statement of Claim or by whatever name called) are not evidence. They are averments of the proof of which is submitted to the trier of fact. Evidence is the means by which those averments are proved or disproved. The Court opined on the need to dispense justice effectively before the national courts. In discharging

21 EACJ, First Instance Division Reference No. 15 of 2014.

22 EACJ Appeal No. 1 of 2015. 
judicial duties, the Court expressed, although speed is good justice is even better and often, justice hurried is justice buried.

Notable features from the jurisprudence of the EACJ appertain to its human rights jurisdiction. In James Katabazi-v-Secretary General of the EAC, ${ }^{23}$ the Court held that while it did not have jurisdiction over human rights violations per se, it may still consider human rights violation if it falls under the provisions of Article 27(1) of the EAC Treaty. It was noted that one role of the Court is to interpret the Treaty (Article 27(1)), which includes "respect for the rule of law" as per Article 6(d). ${ }^{24}$ The Court stated that the overriding consideration of the rule of law is that both the rulers and the governed are equally subject to the same law of the land. In Attorney General of Rwanda-v-Plaxeda Rugumba ${ }^{25}$ the Appellate Division found that although the EACJ does not yet have jurisdiction to adjudicate disputes concerning human rights per se, Article 6(d) of the EAC Treaty and Article 6 of the African Charter allow the Court to assert jurisdiction over human rights claims. In Samuel Mukira Mohochi v. Attorney-General of Uganda ${ }^{26}$ the Court re-iterated that whereas there are no human rights provisions in the EAC Treaty, the Court does have jurisdiction over breaches of the State's obligations under Articles 6(d), 7(2) and 104 of the Treaty and Article 7 of the East African Common Market Protocol. The Court in expressing that human rights infringements establish a legal foundation for jurisdiction under Article 27(1) of the Treaty stressed that the obligations in Article 6(d) are serious government obligations of immediate and consistent conduct.

In Mary Ariviza and Okotch Mondoh v. Attorney General of Kenya and Secretary General of the East African Community, ${ }^{27}$ the EACJ affirmed that "due process" is a component of the "rule of law" and defined it as the "following of laid down laws and procedures." In Henry Kyarimpa-v-Attorney

23 EACJ, First Instance Division, Reference No. 1 of 2007.

24 Article 6 (d) of the EAC Treaty provides that one of the fundamental principles of cooperation in the Community is good governance including adherence to the principles of democracy, the rule of law, accountability, transparency, social justice, equal opportunities, gender equality, as well as the recognition, promotion and protection of human and peoples rights in accordance with the provisions of the African Charter on Human and Peoples' Rights.

25 EACJ Appellate Division, Appeal No. 1 of 2012.

26 EACJ First Instance Division, Reference No. 5 of 2011.

27 EACJ First Instance Division, Ref. No. 7 of 2010. 
General of Uganda, ${ }^{28}$ the EACJ Appellate Division expressed that the Court cannot act in vain. The Court affirmed:

We must say that when we don our gowns, step out of our chambers, and enter the temple of justice to do our sacred duty of dispensing justice, we never ever leave our common sense outside. As a Court of Law, we cannot act in vain... Decisions of this Court under Article 30 of the Treaty are decisions in rem (binding as against both the parties and non parties alike) and not in personam (binding only on the parties before the court). The Court cannot shirk its duty to make such decisions because third parties who have not been afforded an opportunity to be heard are thereby affected. ${ }^{29}$

In Henry Kyarimpa - v-Attorney General of Uganda ${ }^{30}$ the Appellate Division further expressed that:

... When the Court has to consider whether particular actions of a Partner State are unlawful and contravene the Principle of the Rule of Law under the Treaty, the Court has jurisdiction, and, indeed, a duty to consider the internal laws of the Partner State and apply its own appreciation thereof to the provisions of the Treaty. The Court does not and should not abide the determination of the import of such internal law by the National Courts. By parity of reasoning, it should be equally obvious that when what is alleged to be a violation of the Treaty Principle of the Rule of Law is the disobedience of an order of the Court of a Partner State, the Court should not abide the determination, if any, by such National Court on whether such Court's order has been disobeyed. It is for this Court to satisfy itself, without the input of the National Court, whether there has been disobedience or disregard of a Court order and to apply that finding in the interpretation of the Treaty.

28 EACJ Appeal No. 6 of 2014.

29 Article 30 of the EAC Treaty stipulates that any person who is a resident in a Partner State may refer for determination by the Court, the legality of any Act, regulations, directive, decision or action of Partner State or an institution of the Community on the grounds that such Act, regulation, directive, decision or action is unlawful or is an infringement of the provisions of the Treaty.

EACJ Appeal No. 6 of 2014. 


\section{Emerging Jurisprudence from National Courts on Enforcement and Implementation of Community Law}

The national courts of the EAC Partner States have jurisdictional competence to consider and determine matters relevant to the Community. ${ }^{31}$ Most of the cases that have been urged before national courts pertain to the implementation and enforcement of the EAC Customs Management Act. The Act provides the legal framework for the trade regime of the Community. The Act is the foundation for private sector engagement and involvement in the Community; it embodies the market driven component of the EAC cooperation.

In criminal matters, unless otherwise expressly specified, offences under the Act are dealt with in accordance with the laws on criminal procedure of a Partner State. ${ }^{32}$ In civil cases, the applicable law is the law of the Partner State with the relevant court being the national court with national pecuniary jurisdiction.

The EAC Customs Management Act lays out procedures to be followed in the resolution of customs disputes. Any suit or action under the Act may be brought in the name of the Commissioner and the Commissioner may sue and be sued in the name of the Commissioner. ${ }^{33}$ The Commissioner may, where satisfied that a person has committed an offence under the Act in respect of which a fine is provided or in which anything is liable to forfeiture, compound the offence and may order such person to pay an amount of money not exceeding the fine which the person would have paid if prosecuted or convicted of the offence. ${ }^{34}$ However the Commissioner may not exercise the power to compound unless the person admits he has committed the offence and requests the Commissioner to compound the offence.

In the Tanzanian case of Tanzania Revenue Authority-v-Murtazar Hussein $B u d h a,{ }^{35}$ the Revenue Authority in the exercise of its powers under section 219 (1) of the EAC Customs Management Act charged the respondent with the offence of being found in possession of uncustomed goods contrary to Section 200 of the Act and Section 47 of the Value Added Tax (VAT) Act. The trial court held that "orders emanating from compounded offences under Section 219 of the Customs Management Act lack forum of enforcement." This finding by the Tanzania national court portends a challenge to enforcement of the EAC

31 Article 33 of the EAC Treaty.

32 Section $220(2)$ of the EAC Customs Management Act.

33 Section 221 of the EAC Customs Management Act.

34 Section 221 of the EAC Customs Management Act.

35 Tanzania Criminal Appeal No. 285 of 2008. 
Customs Management Act. From the perspective of the Revenue Authority, the ruling diminishes the advantages of compounding offences.

Where a person is dissatisfied with the decision of the Commissioner, he or she may lodge an application for review to the Commissioner within 30 days of the decision. Section 230 (1) of the EAC Customs Management Act provides that appeals from the decision of the Commissioner under Section 229 of the Act lie to the Tax Appeals Tribunal established under Section 231. The appeal ought to be lodged within 45 days of the Commissioner's decision.

In the Ugandan case of KawukiMathias- - -Commissioner General of Uganda Revenue Authority, ${ }^{36}$ the Ugandan High Court held that the statutory procedure under the EAC Customs Management Act must be followed; that when statute prescribes a certain procedure, it is unlawful to follow a different procedure. In the Uganda case, the applicant Mr. Kawuki Mathias filed an originating Notice of Motion before the Commercial Division of the High Court under Section 98 of the Civil Procedure Act seeking release of his container of imported cargo comprising of sandals. The Ugandan Revenue Authority objected to the suit on the ground that the suit was prematurely instituted, bad in law and ought to be dismissed. It was contended that the Applicant should have exhausted the procedures provided for under the EAC Customs Management Act before filing the application. Section 230 (1) of the EAC Customs Management Act provides that appeals from a decision of a Commissioner under Section 229 of the Act lie to the Tax Appeals Tribunal established under Section 231. Taking into consideration the above provisions, the Ugandan High Court held that the application was prematurely filed for not having exhausted the appeal procedures under Section 231 of the EAC Customs Management Act.

Principles and concepts from administrative law have been adopted and applied by the national courts in the enforcement and implementation of Community law. It has been expressed that in the implementation of the EAC Customs Management Act, the trading parties have a legitimate expectation that they would not be compelled to meet tax obligations which are not imposed by the law; that the revenue authorities shall not demand taxes or import duty when the law does not provide for the same; and that nationals would not be made to bear unlawful tax obligations.

In Greenberg Trading Limited-v-Kenya Revenue Authority, ${ }^{37}$ it was held that the doctrine of legitimate expectations applies in the implementation of the 
EAC Customs Management Act. ${ }^{38}$ The Court expressed that it is a legitimate expectation of an import duty payer that, once a tax liability arises, the Revenue Authority would notify the tax payer and demand payment of the same and in doing so, the Authority would specify how the liability arose, the transactions in question and how the same is payable. The Court expressed that it is a legitimate expectation that the regular practice of the Revenue Authority is that once goods have been verified and duty thereon paid, the Authority would release the goods to the importer. It must be noted that in Coastal Bottlers Limited-v-Commissioner of Domestic Taxes, ${ }^{39}$ it was held that when an act is against the law, the doctrine of legitimate expectations is inapplicable.

Apart from the doctrine of legitimate expectations, national courts have held that in implementation of the EAC Customs Management Act, the Revenue Authority is under obligation to observe the rules of natural justice. Under the Act, the Commissioners of Revenue Authorities in all the EAC Partner States have wide powers to assess and levy import duty, VAT, to seize goods and to compound offences. It has been expressed that these powers must be exercised in accordance with the rules of natural justice and fair administrative action. In Major General David Tinyefuza-v-Attorney General, ${ }^{40}$ the Uganda Constitutional Court expressed that

the notion of a subjective or unfettered discretion is contrary to the rule of law. All power has legal limits and the rule of law demands that the Courts should be able to examine the exercise of discretionary power. If therefore the executive in exercising its discretion under an Act of Parliament has exceeded the four corners within which the Parliament has decided it can exercise its discretion, such an exercise of discretion would be ultra vires the Act and a court of law must be able to hold it to be so.

In Kenya Revenue Authority v. Spectre International Limited, ${ }^{41}$ the Kenya Court of Appeal re-affirmed that:

38 The concept of legitimate expectation arises where in a particular situation a person has an expectation that a public body or private parties will retain a long-standing practice or keep a promise. Legitimate or reasonable expectation may arise either from an express promise given on behalf of a public authority or the existence of a regular practice which the claimant can reasonably expect to continue.

$40 \quad$ Uganda Constitutional Petition No. 1 of 1996.

41 Civil Appeal No. 235 of 2010. 
it is trite law that persons charged with statutory powers and duty ought to exercise the same reasonably and fairly and the discretion ought not to be exercised whimsically, unreasonably, arbitrarily or against the tenets of natural justice. If the discretion is used arbitrarily or unreasonably, the court may step in to remedy the situation.

An aspect of the EAC trade regime that has been adjudicated by a Partner State court relates to product classification and product valuation under the EAC Customs Management Act. Article 8 (2) of the Customs Union Protocol stipulates that the Partners States shall adopt the "Harmonized Commodity Description and Coding System" for product classification and follow the opinion of the World Customs Organization.

In BETA Healthcare International Limited-vs- Kenya Revenue Authority, ${ }^{42}$ the dispute related to classification of a product either as a medicament or a food supplement. The applicant had imported Sandoz Calcium Forte- 500 and declared the goods as medicaments and paid zero import duty. On the other hand, the Revenue Authority upon conducting a post clearance audit classified the imported goods as food supplement liable to import duty Ksh. $127,795,427$. The applicant requested for an opinion of the classification of the goods from the World Customs Organization. The High Court held that the opinion of the World Customs Organization classifying the product as food supplement was binding. The Court observed that under Section 126 of the EAC Customs Management Act the customs authority is required to apply or interpret the section and the 4th Schedule on product classification after taking into account the decisions, rulings, opinions and interpretations given by the directorate, wTo or the Customs Cooperation Council.

The Uganda High Court has had an opportunity to consider and determine the implementation of EAC Customs Management Act in relation to product valuation. In Testimony Motors - v-Commissioner of Customs Uganda Revenue Authority, ${ }^{43}$ the Ugandan Revenue Authority unilaterally suspended the use of the transaction value and adopted the alternative method for customs valuation. The action against the Revenue Authority was for a declaration that the directive to unilaterally suspend the operation of the transaction value method provided in Section 122 and the 4th Schedule of the EAC Customs Management Act was arbitrary and unlawful. The interpretative notes of the Act provides that the methods of valuation are set out in sequential order of application and the primary method of customs valuation is defined in paragraph 2 to be

\footnotetext{
42 Miscellaneous. Application No. 4 of 2009.

43 High Court Case No. 212 of 2012.
} 
the transaction value method. The Ugandan Court issued a declaration that the directive of the Commissioner of Customs of the Uganda Revenue Authority to suspend the operation of the transaction value method was unlawful to the extent that it excluded the application of the transaction value method for assessment of customs duty.

The relationship between the EAC Customs Management Act and the fundamental right to property and detention of goods for non-payment of duty has been considered by the national court in Kenya. In Cyrwan Enterprises- $-v$ Kenya Revenue Authority, ${ }^{44}$ the petitioner challenged the constitutionality of the provisions of the EAC Customs Management Act that permitted the Kenya Revenue Authority officials to intercept and detain goods they considered suspicious until duty was paid. It was argued that the Act was contrary to Article 40 of the Kenya Constitution that protects the right to property. ${ }^{45}$ It was argued that the powers of the Revenue Authority to intercept and detain goods were an arbitrary detention of one's property. The Court held that collection of taxes was an important component of the modern state and statutes governing collection of taxes are consistent with the letter and spirit of the Constitution. It was observed that the provisions of EAC Customs Management Act were part of a statutory scheme aimed at efficient and effective collection of customs duty; that Section 210 of the Act only set out the kind of goods liable to forfeiture and did not empower the revenue authority to arbitrarily take a person's property. It was noted that taking the provisions of impugned sections within the context of the entire Act, the EAC Customs Management Act demonstrates that forfeiture is not arbitrary but is subject to reasonable grounds. Moreover, the Court observed that there was a procedure for determining the rights of a party whose property had been seized on account of suspicion of breach of the EAC Customs Mangement Act and for the Commissioner to secure the collection of taxes. The Court concluded that Sections 210 and 211 of EAC Customs Management Act were not unconstitutional or in violation of Article 40 of the Constitution of Kenya. In Kasibo Joshua - v-Commissioner of Customs, Uganda Revenue Authority, ${ }^{46}$ it was held that it was wrong to forfeit and condemn the goods if the fines and penalties imposed were wrong in the first place.

\footnotetext{
44 High Court Constitutional Petition No. 322 of 2011.

45 Article 40 (1) of the Kenya Constitution provides inter alia that every person has the right either individually or in association with others to own and acquire property. Article 40 (1) stipulates that the State shall not deprive a person of property of any description or of any interest in or right over property of any description unless the deprivation is for a public purpose and provision is made for compensation. 
Apart from the adopting principles of administrative law, the practical aspects of regional trade integration has been a subject of adjudicate by national courts. One of the factors determining successful regional integration is trade facilitation. Trade facilitation provides an important opportunity for integrating countries to increase the benefits from open trade, and contributing to economic growth and poverty reduction. ${ }^{47}$ The infrastructural and logistical aspects of trade facilitation have impact on efficient and effective movement of goods within and among the integrating States.

Trade facilitation focuses inter alia on transactions at the border, such as documentary requirements, transparency of customs clearance and transit procedures, and disciplines on fees and taxes. Comprehensive trade facilitation examines the costs that traders and producers face from production until the delivery of their goods and services to the overseas buyer and thereby includes all the transaction costs both directly and indirectly associated with the trading process. In regional integration, the legal framework for trade facilitation is significant. A vital logistical aspect for regional trade is clearance of goods at the port of entry either for domestic consumption, transit to frontier states or goods destined for Export Processing Zones in a Partner State.

Port clearance of goods is largely handled by clearing agents and the issue liability of owner of goods for acts of a duly authorized agent is a pertinent question in customs law. Once goods have entered a Partner State, Regulation 174 of the EAC Customs Management Act provides that a security bond shall be furnished to cover movement of goods between points of importation and re-exportation or transit.

In Alltex EPZ Ltd. - v-Kenya Revenue Authority, ${ }^{48}$ the applicant was licensed to manufacture goods under bond as an Export Processing Zone (EPZ) within the meaning of Section 160 of the EAC Customs Management Act. An employee of Alltex fraudulently cleared some goods destined for the EPZ and diverted them into the Kenya domestic market. The Revenue Authority demanded import duty for the fraudulently cleared goods. The legal issue was whether a licensee must pay taxes secured by the security bond when the imported goods destined to the EPZ are diverted by criminal or delinquent acts of an employee. It was argued that the licensee was not liable to pay taxes as the criminal acts of the employee were not done in the course of employment; that once an employee is engaged in fraud he was outside the scope of his employment. The Revenue Authority submitted that there are judicial decisions to support the position that a tax payer is liable to pay tax notwithstanding the criminal or

47 World Bank, Policy Note No: 27 by Barbara Rippel November, 2011.

48 Miscellaneous Application No. 709 of 2008. 
delinquent conduct of the employee (See $R v$. Kenya Revenue Authority ex parte Africa Boot Limited, HC Misc. App No. 24 of 2010; $R$ - $v$-Commissioner of Customs ex parte Transami $(K)$ Limited..$^{49}$ The Kenya High Court citing $R$ - $v$-Commissioner of Customs ex parte Transami $(K)$ Limited ${ }^{50}$ held that an owner of any goods who authorizes an agent to act for him is liable for the acts and declarations by the agent. Citing with approval the decision in Rv. Kenya Revenue Authority ex parte Africa Boot Limited, ${ }^{51}$ the Court emphasized that when a customs agent engages in fraudulent activities, the importer has to bear the loss with fortitude and find a way of recovering the money misappropriated from the customs agent; that a prudent tax payer will always monitor the activities of its agent so as to ensure compliance with the law.

In the realm of intellectual property, the case of $R$ - $v$-Kenya Revenue Authority ex parte Bata Shoe Company $(K) L t d,{ }^{52}$ provides a case study on the interface between intellectual property rights, customs and value added tax in the context of the EAC Customs Management Act. One of the grounds raised by Bata Shoe Co. (K) Limited as the applicant was that the Revenue Authority's decision to demand payment of taxes on royalties the applicant paid to an entity known as Bata Brands was ultra vires the EAC Customs Management Act and the Revenue Authority's powers. According to the applicant, the distribution royalties is not subject to customs duty as they are not royalties related to the goods being valued that the buyer must pay within the meaning of Rule 9(i) (c) of the 4th Schedule to the EAC Customs Management Act. It was contended that subparagraph 1 (c) to the Note on Interpretation of Rule $9(i)$ (c) of the 4 th Schedule provides that-

Payments made by the buyer, for the right to distribute or resell the imported goods shall not be added to the price actually paid or payable for the imported goods if such payments are not a condition of sale for export to Partner state of the imported goods.

The applicant maintained it was not obliged to pay the customs and VAT on the buying commission by virtue of the provisions of Paragraph 1 of the Note of Interpretation of Paragraph 2(1) of the 4 th Schedule which provides that:

\footnotetext{
49 Nairobi High Court Miscellaneous Application No. 81 of 2011.

5o Nairobi High Court Miscellaneous Application No. 81 of 2011.

$51 \quad$ High Court Miscellaneous Application No. 24 of 2010.

$5^{2}$ Judicial Review Case No. 36 of 2011.
} 
the price actually paid or payable is the total payment made by the buyer to or for the benefit of the seller for the imported goods.

The Revenue Authority in demanding customs duty contended that payment of duty was permitted under Section 122 and paragraph 9(1) (c) of the 4th Schedule. It was submitted that the Interpretive Notes to paragraph 9(1) (c) clarify that royalties and licence fees may include among other things payment in respect of patents, trademarks and copyrights. The Revenue Authority asserted that two conditions must be established for chargeability of royalties namely, the royalty payment relates to the goods being valued and the royalty is paid pursuant to a condition of sale. It was the Revenue Authority's case that both conditions were satisfied in relation to the goods sold by the applicant. The Revenue Authority cited the case of Republic v Kenya Revenue Authority ex-parte Beirsdorf East Africa Ltd, ${ }^{53}$ where it was expressed:

.... payment of royalties by the applicant to Biersdorf is a condition of sale of their imported patented goods. I agree with the respondent that if royalties were not a condition of sale anyone would be at liberty to import, manufacture or even distribute Biersdorf's products without permission of the patent holder. That would be an unacceptable trade practice. The relevant law must be interpreted in a manner that makes economic sense. The only instance in which payments made by a buyer for the right to distribute or resale imported goods may not be added to the price actually paid or payable for purposes of determining custom value is where the payments (including royalties) are not a condition of sale.

The trial court in $R-v$ - Kenya Revenue Authority ex parte Bata Shoe Company (K) $L t d,{ }^{54}$ observed that the royalty fees paid to Bata Brands by Bata Shoe (K) Limited were payable in respect of imported goods as well as goods manufactured locally. The Court held that the royalty fees were paid for the use of the trademarks in Kenya and they had nothing to do with the prices of imported products. The Court expressed that it would be a herculean exercise to try and separate royalties for locally manufactured goods and imported goods so as to find out what the price payable for the imported goods is. The Court concluded that the Court was not the forum for assessment of taxes, that it is the duty of

53 Nairobi High Court Miscellaneous Application No. 413 of 2009.

54 Judicial Review Case No. 36 of 2011. 
the Revenue Authority to assess the tax due and payable and the court will not interfere with the statutory functions of the Revenue Authority.

Aside from trade in goods, the trade regime of the EAC incorporates trade in services. Partner States have undertaken to adopt measures to achieve free movement of services. ${ }^{55}$ The case of Barclays Bank of Kenya Limited- $-v$-Kenya Revenue Authority, ${ }^{56}$ is a pointer on how Kenyan courts deal with taxation of service charge on credit card transactions in cross border trade in services. The relevant facts of the case are that Barclays Bank (K) Limited enables its customers to make payment for goods and services in Kenya and elsewhere using credit card instead of cash. To provide credit card services, the Bank is a member of a wide network operated by international credit card companies such as VISA CARD, American Express (AMEx) and Master Card. These companies administer a world-wide consumer payment system which enables their members to provide their customers with the means of making payment. Barclays Bank (K) Limited pays various fees to the Card companies to access the networks. The fees paid to the card companies include Association Fees, Quarterly Service Fees, International Service Fee, and VISANET (internet software licence) Service fee, Interchange fees (for clearing and settlement fees, risk monitoring) and compliance fee between issuers of the card and the networks. The issue in the Barclays case was whether such fees are royalty or professional management fee subject to withholding tax under the provisions of the EAC Customs Management Act and the relevant Kenya revenue laws. The Kenyan High Court held that such fees are not royalty and are not professional management fees subject to withholding tax.

\subsection{Emerging Jurisprudence on Recognition and Enforcement of Foreign Judgments in EAC}

The EAC Treaty calls for "standardization of judgments of courts within the Community" and cooperation in "judicial and legal matters with a view to harmonizing their judicial and legal systems". ${ }^{57}$ Each of the Partner States has national courts which delivers judgments that may need to be enforced and executed in another Partner State's national jurisdiction. The EAC Treaty in Article 44 provides the legal framework for execution of EACJ judgments in the Partner States. However, the legal framework for execution of a Partner State

\footnotetext{
55 Article 104 (1) of the EAC Treaty.

56 Misc. Appl. No. 1223 of 2007.

57 Article 126 (1) of the EAC Treaty.
} 
national judgment in the territory of another Partner State is a subject that is not dealt with by the Treaty. This issue depends on the national legal framework for execution of foreign judgments.

Kenya, Uganda and Tanzania have Foreign Judgment Reciprocal Enforcement Acts which permit judgments of each Partner State's national court to be enforced and executed in another Partner State. ${ }^{58}$ The respective Acts of each country has designated the other countries as designated countries for purposes of foreign judgment reciprocal enforcement.

In Kenya, enforcement of foreign judgments is the subject of The Foreign Judgments (Reciprocal Enforcement) Act (Cap 43 of the Laws of Kenya). The objective of the Act is to make provision for enforcement of judgments given in countries outside Kenya which accord reciprocal treatment to judgments given in Kenya. Litigation on enforcement of foreign judgment has been considered in various cases in Kenya. In Intalframe Ltd-v-Mediterranean Shipping Company, ${ }^{59}$ it was held that the basic principle upon which neighbouring or other states provide enforcement of foreign judgments is one of reciprocity. (See also Ssebaggala \& Sons Electric Centre Limited-v-Kenya National Shipping Lime Limited; 60 Pioneer General Assurance Society Limited-v-Zilfikarali Nimji Javer; ${ }^{61}$ Societe de Transports International Rwanda-v-H. Abdi. ${ }^{62}$

In Jayesh Hasmukh Shah-v-Navin Haria \& another, ${ }^{63}$ enforceability of a foreign judgment from non-designated country was considered. The appellant sought to enforce and execute in Kenya a judgment from Ethiopia which is not a designated country under the provisions of Foreign Judgments (Reciprocal Enforcement) Act (Cap 43 of the Laws of Kenya). The Kenya Court of Appeal held that in the absence of a reciprocal enforcement arrangement, a foreign judgment is enforceable in Kenya as a claim in common law. The common law principles on enforcement of foreign judgments were extensively elaborated in the case of Adams \& Others-v-Cape Industrials PLC. ${ }^{64}$ Another relevant case law on enforceability of foreign judgment from a non-designated country is the Uganda case of Christopher Sales \& Another- $v$ - The Attorney Genera. ${ }^{65}$

58 See Tanzania, The Reciprocal Enforcement of Foreign Judgments Act, Chapter 8 of the Laws of Tanzania; see Uganda Foreign Judgments (Reciprocal Enforcement) Act Chapter 9 of the Laws of Uganda.

59 (1986) KLR.

6o (2000) LawAfrica LR 931.

61 (2006) eKLR.

62 Civil Application No. NAI 298 of 1997.

63 [2016] eKLR, Nairobi Civil Appeal No. 147 of 2009.

64 (1990) Ch. 433.

65 Uganda HCCC No. 91 of 2011. 
In this case, the Uganda High Court held that a foreign judgment from the United States of America (USA) was enforceable in Uganda despite the fact that the USA was not a designated country under the provisions of Uganda Foreign Judgments (Reciprocal Enforcement) Act (Cap 9, Laws of Uganda).

\subsection{Conclusions and Recommendations}

The emerging jurisprudence from the EACJ and the national courts of the Partner States depict a positive trend towards development of local jurisprudence in the interpretation and application of Community law. Most of the cases before the EACJ are premised on violation of EAC Treaty provisions particularly the Articles on good governance and rule of law. Through the craft of judicial interpretation, human rights litigation has found its way into the EACJ jurisdictional competence. It is observable that the EACJ is making positive contribution to Community jurisprudence on the rule of law, good governance and respect for human rights. The Court's decisions play a role in putting the national governments of the Partner States under check and control. Likewise, the residents of the EAC Partner States have found a supranational forum at which they can ventilate grievances on violation of their fundamental rights and freedoms. The Bar Associations have also found an additional forum in which to practice and sharpen their advocacy skills. To this end, the EACJ plays a significant role in human resource capacity building on regional integration issues within the Community. The Court is incrementally institutionalizing the rule of law within the Community.

On trade liberalization, disputes on interpretation and application of the EAC Customs Management Act have rarely found their way before the EACJ. There is limited litigation before the Court on the EAC Trade Regime. The EACJ has received no single case on the EAC Customs Union. In 2008, Mordern Holdings - $v$-Kenya Ports Authority, ${ }^{66}$ filed a customs union reference case but the Court dismissed it for want of jurisdiction. The dismissal of this case by the Court for lack of jurisdiction was a big blow to the business community that has since shunned the Court.

In a majority of the cases before the EACJ, the applicants are natural persons or Bar Associations of the Partner States. Litigation by the business community or commercial corporate entities is very limited before the Court. There is need to encourage the private sector to be active before the Court. The limited participation of the business community may be explained by the establishment 
of parallel EAC Dispute Resolution Mechanisms (Quasi Judicial Bodies). Much as the EACJ is the main judicial organ of the Community, the EAC Partner States continue to establish other quasi-judicial bodies or mechanisms with the same mandate as the EACJ. The Customs Union and Common Market Protocols are an example where parallel mechanisms have been established with potentialities of making EACJ redundant or be a cause for conflicting decisions in the region. ${ }^{67}$ Under Article 54 (2) of the EAC Common Market Protocol, jurisdiction to entertain Common Market related disputes has mainly been given to national courts and this undermines the EACJ.

From an administrative point of view, one of the challenges facing the EACJ is its intermittent and an ad-hoc nature. The EACJ does not have any continuous sittings; the court sits in sessions and this delays disposal of cases and hinders efficiency. The current work load of the EACJ does not require all the Judges to reside permanently in Arusha where the seat of the Court is located. However, it is recommended that when the work load of the Court increases, the possibility of continuous sitting should be explored. Another challenge is the reluctance of the Partner States to explicitly extend the jurisdiction of the EACJ to include human rights issues.

At the national level, disputes before the Partner States court are customs related and are founded on the EAC Customs Management Act. Rarely has an issue relating to interpretation and application of the EAC Treaty been considered for determination by the national courts. In most cases, the private sector is active as the applicants before the national courts. The active participation is due to enforcement of the EAC Customs Management Act by national Revenue Authorities as they collect revenue for their national governments. Time lag between the filing of complaint before the national court and the determination of the dispute is a factor that should be considered if dispute resolution before national courts can effectively contribute to regional integration.

67 The dispute resolution mechanism put in place by the EAC Customs Union Protocol is in Annex IX of the Protocol. See also the East African Committee on Trade Remedies established under Article 24 of the EAC Customs Union Protocol. 